Vol. 4, Issue.6, Nov-Dec 2021, page no. 385-397

To cite this article: Dr. Liu Yue, Wang Zhiwen and Lin Sisi (2021). THE IMPACT OF CHINA'S COMMODITY HOUSE PRICES ON FERTILITY RATE UNDER THE LOW BIRTH RATE, International Journal of Education and Social Science Research (IJESSR) 4 (6): 385-397

\title{
THE IMPACT OF CHINA'S COMMODITY HOUSE PRICES ON FERTILITY RATE UNDER THE LOW BIRTH RATE
}

\author{
Dr. Liu Yue, Wang Zhiwen and Lin Sisi \\ Wenzhou Polytechnic, China
}

DOI: http://dx.doi.org/10.37500/IJESSR.2021.4627

\begin{abstract}
In recent years, the continuous decline of China's birth rate has become the focus of academic attention. Studying house prices and the birth status of residents in the same framework will help to explore the role of house prices in household micro-asset allocation, help to find effective measures to curb the unreasonable rise of house prices, and achieve the purpose of adjusting the number of population and structure. The results of the study found that house prices have a significant negative impact on the birth rate, and the excessive growth of house prices has a significant inhibitory effect on the birth status of residents.
\end{abstract}

KEYWORDS: Low Birth Rate; Commercial House; Price; Fertility Rate; China

\section{INTRODUCTION}

The low fertility rate will not only accelerate aging, but will also cause labor shrinkage and labor costs to rise. The fertility rate of an international country has a clear correlation with its GDP growth rate. Due to the long-term existence of low fertility rates in developed countries such as Europe and Japan, the GDP growth rate of their countries has remained at a low speed. Because the United States has a steady stream of immigrants to provide labor, the economic growth rate of the United States maintains a relatively high position among developed countries. If a country's fertility rate remains low for a long time and there are no immigrants, the country's GDP growth rate will slow down, or even turn into a negative growth. The most obvious one is Japan. According to the current fertility rate, the total population of Japan may be reduced to 1,000 in 2500; Koreans may become extinct in 700 years. In addition, Singapore, Bosnia and Herzegovina, Lithuania, and Ukraine are all facing the danger of population extinction.

Data from China's seventh census in 2020 show that the national fertility rate has dropped to around 1.3, which is far lower than the natural replacement fertility rate of the population. As of the end of 2020, China's birth rate has declined from $23.3 \%$ in 1987 to $8.5 \%$. The sharp decline in the birth rate and natural population growth rate indicates that China is close to the "ultra-low fertility trap" (Lutz, 2014), which may have a serious impact on China's sustained economic growth and social structure 
optimization. According to the "Analysis and Forecast of China's Economic Forms in the Economic Blue Book 2015" issued by the Chinese Academy of Social Sciences, China's current total fertility rate is only 1.3 , far below the replacement level of 2.1, while the internationally recognized low-fertility trap has a fertility rate of 1.3 .

Historically, China has been deeply influenced by traditional Confucian concepts and has always paid attention to the inheritance of children. But why are people increasingly reluctant to have children, causing the birth rate to drop so fast? Since the beginning of this century, the process of urbanization in China has gradually accelerated, and the reform of the land system has led to a rapid rise in urban real estate prices. The new situation that accompanies the high house prices is that China's fertility rate has continued to slump, and population growth has transitioned to the current "three lows" situation of low fertility, low mortality, and low growth rate. So, can we think that the rapid rise in house prices in recent years has also played an important role in the decline in fertility? The resolution of these problems has important reference significance for formulating reasonable population policies and real estate control policies. Based on this, this article will study the impact of commercial house prices on residents' fertility behavior.

\section{LITERATURE REVIEW}

The population issue is related to the national economy, people's livelihood and the country's longterm development, and has always attracted the attention of sociologists and economists. The Malthus model (Malthus, 1798) believes that the marginal productivity of labor exceeds the marginal productivity of capital, and rising wages stimulate fertility, increase labor supply, and restore the economy to its initial equilibrium wage level. Therefore, in the absence of endogenous technological growth, the equilibrium wage level in the Malthus model will be determined by the preference for fertility. A higher fertility rate reduces the equilibrium capital-labor ratio, thereby reducing the equilibrium per capita income level. The industrial revolution Some corrections have been made to this model.

With the continuous increase of per capita income in the 19th and 20th centuries, the fertility rate has shown a long-term downward trend in Europe, America and Japan (Butz and Wald, 1979). This counter-economic growth fertility trend does not show signs of returning to its initial equilibrium (Easterlin, 1976). Therefore, Becker established a new fertility rate analysis framework within the neoclassical paradigm. This analytical framework has gradually become the mainstream framework for fertility research in the subsequent development (Gronau, 1973; Willis, 1973), and is called "New Family Economics" (Becker, 2013). In the basic theoretical model of new family economics, the level of fertility depends on the balance between the income effect of surplus demand and the substitution effect. That is to say, according to the traditional division of labor in the family, both the husband's income and the wife's income affect fertility. The main factor. Because in the traditional division of labor in the family, the husband mainly provides economic income for the family, while the women 
are mainly engaged in housework and caring for the children, so in addition to the necessary daily necessities, the time value of women (that is, the wage rate) has also become the shadow price of childbirth.(Sprague, 1988).Among them, the influence of the husband's wage rate on fertility is mainly manifested in the income effect, while the influence of the wife is mainly the substitution effect (Willis, 1973).The final fertility rate is the result of the superposition of the income effect of the fertility demand and the substitution effect (Yakita. 2018). Becker, Duesen berry and Okun believe that the rise in various living and social costs has led to a long-term decline in fertility. Becker treats children as durable goods and analyzes the fertility determination problem, and finds that residents' income, child support costs, knowledge, uncertainty, and preferences are the determinants of fertility.

With the changes in the economic environment and social patterns, some phenomena that are difficult to explain by the new family economics have appeared in family reproductive behavior. The major changes in the price system of the consumer goods market have led to important reasons for the changes in the shadow price of family fertility. As one of the durable goods with the most dramatic changes in relative prices in the process of economic growth, house has also had an important impact on family fertility behavior (Yi and Zhang, 2010). As a major decision of the family, the purchase of a house will affect other decisions of the family for a long period of time, and the decision of childbirth is one of the main decisions affected. That is, rising house prices reduce the family's disposable income on other consumption, and therefore have a fortune income effect on the demand for childbirth. Assuming that children are normal goods, the negative income effect will reduce the demand for childbirth. Secondly, the more children there are, the larger the house area is needed. Therefore, the house price directly enters the factor price of fertility, and the increase in house price has a certain negative compensatory substitution effect on fertility. Therefore, the inclusion of house prices helps to understand the evolution of fertility behavior in the process of economic growth and urbanization in newly industrialized countries and regions.

Among the existing literatures on the impact of house prices on fertility, one category focuses on the macroscopic study of the effect of rising house prices on fertility. Luc Laeven and Alexander Popov (2017) studied the impact of the house market boom on the fertility-related choices of young Americans based on the regional changes in house price fluctuations in the United States. They found that in areas where house prices rose sharply from 2001 to 2006, young families the proportion of buying houses, getting married and having children has been greatly reduced. Changes in house prices in the United States have two effects on family fertility decisions: On the one hand, rising house prices will have a negative impact on fertility. This applies to both potential first-time buyers and families with houses, who may need a larger house area as their children increase. On the other hand, for families with houses, rising house prices will increase the net value of the house, which will have a positive impact on the birth rate. They confirmed through investigations that the short-term increase in house prices will lead to a decline in the birth rate of households without houses and a net increase in the birth rate of households with houses. Every $\$ 10,000$ increase is estimated to increase the fertility 
rate by $5 \%$. Chen (2013) conducted research on the relationship between Taiwan's fertility rate and house prices, and the results showed that in a low threshold environment, house costs and opportunity costs have more important effects on fertility than the system. Hui Heng and Hu used Hong Kong quarterly time series data from 1976 to 2010 to study the relationship between house prices, old-age dependency ratios and fertility rates, and found that an increase in house prices and old-age dependency ratios by 1 percentage point would lead to a decrease of 0.52 and 1.65 percentage points in the birth rate, respectively. House prices and the old-age dependency ratio are the main reasons for the change in the birth rate. Simon and Tamura used the US Census data from 1940 to 2000 to conduct empirical analysis and found that there is a horizontal negative correlation between unit rent and fertility. On the other hand, it studies the impact of rising house prices on family factors from a micro perspective. Song Deyong et al.(2017) conducted theoretical and empirical analysis based on the micro family decision-making model, and the results showed that rising house prices would significantly reduce the willingness of urban married residents to have a second child; For families with no real estate or only one real estate, due to the increase in house burden, they will give up their willingness to have a second child; for families with 2 or more real estate, the house wealth effect does not increase their willingness to have a second child. Zhang Xinjie(2017) studied the choices between the number and quality of children made by families of different income classes, and believes that the substitution effect between the two is widespread and the substitution effect is most obvious in middle-income families. In summary, the academic circles have conducted in-depth discussions and studies on the reasons for the decline in the fertility rate of residents, but we still believe that there are certain shortcomings。

Most studies have not sorted out the logical relationship between house prices and fertility behavior, and cannot effectively find the impact of real estate price fluctuations on residents' fertility behavior. This article focuses on sorting out the impact logic of house prices and fertility behavior, and analyzing the impact of real estate price fluctuations on the fertility status of residents.

\section{The impact of house prices on reproductive behavior}

Among the factors that promote the rise of house prices, urbanization, residents' income levels and economic development stages all play a very important role (Xu Dianqing,2006). Urbanization is an inevitable requirement and result of economic development, which promotes the increase in house demand. From 1971 to 2005, Hong Kong, China's per capita real GDP increased by 4.8 times, becoming one of the fastest growing regions in the global economy over the same period19.At the same time, its house prices have risen sharply at the same time since the 1970s.During the same period, house prices have increased by 6.7 times, and the rate of increase in house prices has exceeded the rate of increase in real GDP per capita. With the rapid economic development of our country, in the past two decades, we have experienced three big explosions in house prices in China. Unleashing the craziness of house demand from 2004 to 2007, the launch of the four trillion monetary stimulus plan from 2009 to 2013, and the destocking since 2015.In 2000, the average transaction price of newlybuilt commercial house in cities and towns across the country was 2112 yuan/square meter, of which, 
commercial house was 1948 yuan/square meter. By 2019, the average transaction price of newly-built commercial house was 14460 yuan/square meter, and the house price increased by 7.4 times. During the same period, the birth rate dropped from 14.03\% in 2000 to $10.48 \%$ in 2019. Mr. Ren Zeping, chief economist of the Evergrande Economic Research Institute, pointed out that the decline in the birth rate has long affected the number of people of marriageable age. According to the 2010 China Census, the population of the post-80s, post-90s, and post-00s was 219 million, 188 million, and 147 million, respectively. The post-90s generation is about 31 million fewer than the post-80s generation, and the post-00s generation is 41 million fewer than the post-90s generation. According to data from the National Bureau of Statistics, the number of births in China in 2019 was 14.65 million, a decrease of 580,000 from the previous year. The birth rate is the lowest since the beginning of the 21 st century (data not released for 2020). It is not difficult to see that house price growth has a certain impact on the number of births.

\section{GDP, Fertility Rate with House Price}

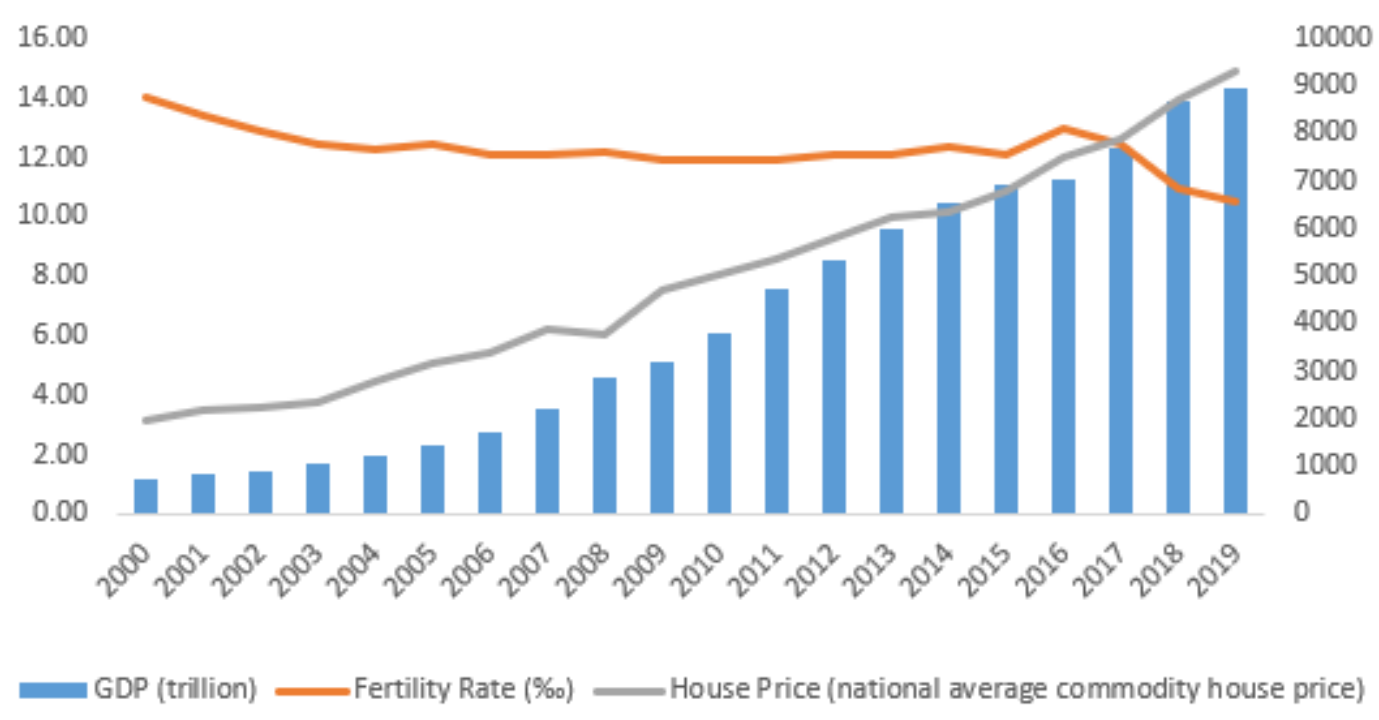

\section{Figure 1 The relationship between GDP, fertility rate and house price (National Bureau of Statistics)}

Figure 1 shows that 2016 was a turning point in the birth rate. At the same time, the GDP growth rate has stabilized from $29 \%$ in the past to less than $10 \%$, while the national average commercial house prices have risen steadily. The high house prices have mainly affected the fertility behavior of Chinese residents. Produced through the following three aspects (see Figure 2) 


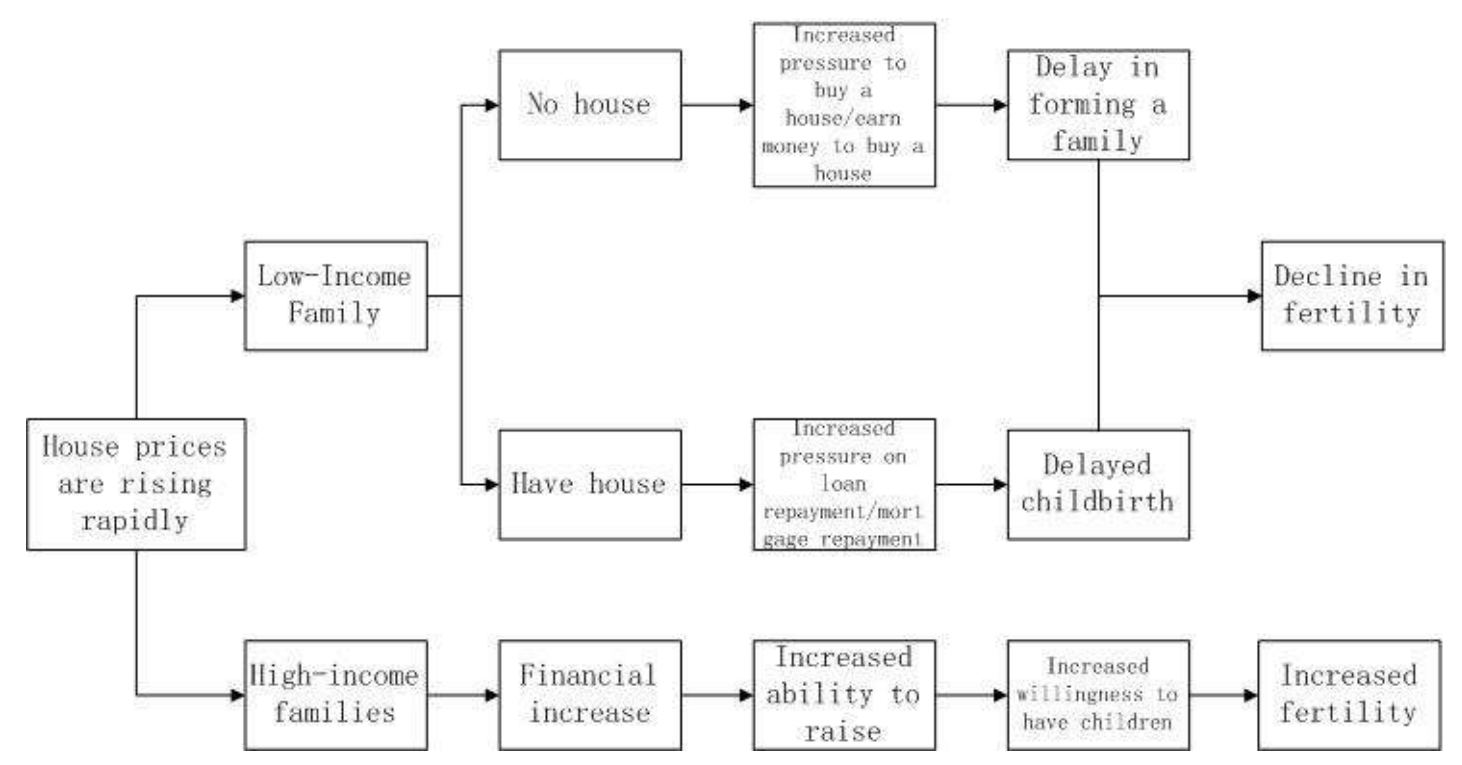

Figure 2 The impact of house prices on family reproductive behavior

\section{High house prices delay the time for young people to organize families}

"Marriage Industry Observation" pointed out that in 2020, 8.131 million marriages were registered nationwide, a year-on-year decrease of $12.2 \%$. The national marriage rate has been declining since 2013. From 2013 to 2020, the number of marriage registrations in China has continued to decline from a historical high of 13.47 million to 8.13 million. The Evergrande Economic Research Institute calculated in the "China Marriage Report 2021" that from 2013 to 2019, the initial marriage rate (the number of marriage declarations per 1,000 people in a year) fell from $9.9 \%$ o to $6.6 \%$.Among them, the number of newly married people dropped from 23.86 million to 13.987 million, and the number of remarried people rose from 3.079 million to 4.559 million. The data in the report shows that between 2005 and 2019, the proportion of registered marriages (including remarriage) aged 20-24 dropped from $47.0 \%$ to $19.7 \%$, 25-29 years old rose from $34.3 \%$ to $34.6 \%, 30-34$ years old, and 35 years old. The proportion of persons aged 39 and over 40 who registered for marriage increased from $9.9 \%, 4.9 \%$, and $3.9 \%$ to $17.7 \%, 8.1 \%$, and $19.9 \%$, respectively. At the same time, Mr. Ren Zeping also pointed out that the current situation of serious imbalance in the ratio of men and women has also caused difficulties in matching the marriage market, which in turn affected the number of marriage pairs. The data shows that the sex ratio (male: female, female=100) of the population born in 1982 was 107.6, exceeded 110 in 1990, approached 118 in 2000, and exceeded 120 for a long time thereafter. The normal range of population sex ratio is between 103 and 107. Due to the influence of traditional house consumption concepts in urban families in China, they adhere to the belief that they must buy a house when they get married, do not get married, and buy a large apartment when buying a house. As a result, many young people living and working in cities do not have their own houses. It will postpone love and marriage. This is also the reason for the huge decline in the number of marriage registrations 


\section{International Journal of Education and Social Science Research}

IJESSR

ISSN 2581-5148

Vol. 4, Issue.6, Nov-Dec 2021, p no. 385-397

between the ages of 20 and 24. This has caused the high house price to become the first child of our national residences and has greatly prolonged, which has an adverse effect on the reproductive behavior of residents.

\section{The increase in house expenditure reduces residents' willingness to have children}

\begin{tabular}{|c|c|c|}
\hline & $\begin{array}{l}\text { Consumer Price Index of } \\
\text { Owned House }\end{array}$ & $\begin{array}{l}\text { Residents Consumer Price } \\
\text { Index of House Renting }\end{array}$ \\
\hline 2001 & 108.6 & 100 \\
\hline 2002 & 104.4 & 95.4 \\
\hline 2003 & 103.5 & 99.1 \\
\hline 2004 & 103 & 100.9 \\
\hline 2005 & 101.9 & 105.6 \\
\hline 2006 & 102.7 & 103.7 \\
\hline 2007 & 104.2 & 107 \\
\hline 2008 & 103.5 & 102.8 \\
\hline 2009 & 101.6 & 85.3 \\
\hline 2010 & 104.9 & 103.6 \\
\hline 2011 & 105.3 & 106.5 \\
\hline 2012 & 102.7 & 102.3 \\
\hline 2013 & 104.1 & 103.8 \\
\hline 2014 & 103.3 & 103 \\
\hline 2015 & 102.6 & 108.6 \\
\hline
\end{tabular}

Table 1 Consumer Price Index of Residents Owned Houses and House Rentals (National Bureau of Statistics of China)

Since the data indicators of the consumer price index of house-owned houses and house rents in Figure 3 given by the Bureau of Statistics are calculated based on the previous year $=100$, we have processed the data and obtained: 


\section{International Journal of Education and Social Science Research}

ISSN 2581-5148

Vol. 4, Issue.6, Nov-Dec 2021, p no. 385-397

\begin{tabular}{|c|c|c|}
\hline & $\begin{array}{l}\text { Consumer Price Index of } \\
\text { Owned House }\end{array}$ & $\begin{array}{l}\text { Residents Consumer Price } \\
\text { Index of House Renting }\end{array}$ \\
\hline 2001 & 108.60 & 100.00 \\
\hline 2002 & 113.38 & 95.40 \\
\hline 2003 & 117.35 & 94.54 \\
\hline 2004 & 120.87 & 99.99 \\
\hline 2005 & 123.16 & 106.55 \\
\hline 2006 & 126.49 & 109.51 \\
\hline 2007 & 131.80 & 110.96 \\
\hline 2008 & 136.41 & 110.00 \\
\hline 2009 & 138.60 & 87.69 \\
\hline 2010 & 145.39 & 88.37 \\
\hline 2011 & 153.09 & 110.33 \\
\hline 2012 & 157.23 & 108.95 \\
\hline 2013 & \begin{tabular}{|c|}
163.67 \\
\end{tabular} & 106.19 \\
\hline 2014 & 169.08 & 106.91 \\
\hline 2015 & 173.47 & 111.86 \\
\hline
\end{tabular}

Table 2 Consumer Price Index of Residents Owned House and House Renting 


\section{International Journal of Education and Social Science Research}

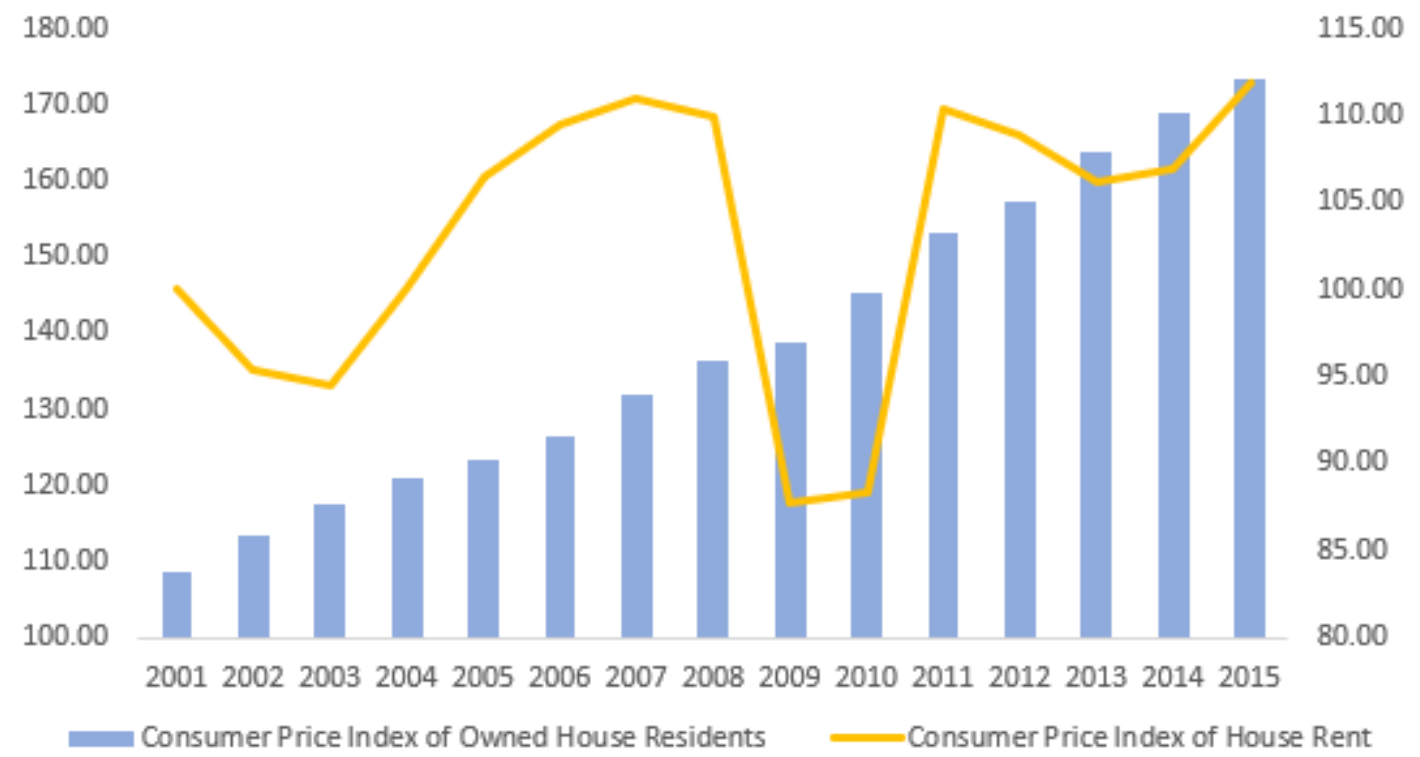

Figure 3 Illustration of consumer price index of self-owned house and house renting

According to Table 1-2 and Figure 3, it can be seen that the consumption index of self-owned house residents is relatively stable, while the consumer price index of house rentals has remained relatively stable from 2001 to 2015 during the data show period. As for the GDP growth rate of 11.4 times, with the steady increase in income levels and the diversification of personal financing methods, many families rely on mortgage loans and provident fund loans to realize their own house, but high house prices still bring greater monthly pressure on them those who have purchased real estate but still need to repay the mortgage are still counted according to the rent category. The Chinese Academy of Social Sciences and the Social Sciences Literature Publishing House jointly released the 2011 "Green Paper on House, China House Development Report (2010-2011)" pointed out: According to internationally accepted practices, the highest monthly repayment rate is $30 \%$. Families above this line are low-income families, and such families generally have to rent a house instead of buying a house. At present, the monthly payment rates of most cities in China have exceeded the highest line, except for a few cities such as Hohhot and Chongqing. Cities with higher monthly payment rates are mainly concentrated in first-tier cities such as Beijing, Shenzhen, Shanghai, and Guangzhou. The highest It is Beijing, and the monthly repayment rate for most months exceeds $100 \%$ shows that the pressure on the repayment of residential mortgages in China is relatively high. Under this circumstance, mortgage loans have a crowding-out effect on family-owned couples' expenses for childbirth and childbearing, resulting in lower willingness to give birth to young couples. In addition, due to the high pressure of urban life, work and life, if parents cannot help take care of their children, it will also make young couples younger. The couple is unwilling to have children.

The 18th meeting of the Standing Committee of the Twelfth National People's Congress deliberated the "Population and Family Planning Law Amendment (Draft)" for the first time on the morning of 
December 21, 2015, and it was officially implemented in 2016.The plenary session proposed that in order to promote the long-term balanced development of the population and gradually improve the population development strategy, China has begun to implement the two-child policy in an all-round way. Even if the policy is inclined and various second-child policy subsidies, the data in Figure 1 shows that the newborn birth rate is still declining year by year.

\section{The rapid rise in house prices has increased the willingness of some families to bear children}

House is a necessary condition for childbirth, and the size of the house can affect the number of children born. Therefore, for families with low mortgage pressure or no mortgage, high house prices invisibly increase their total wealth. This increases the income of raising the next generation. With the full implementation of the national second-child policy, it effectively increases their willingness to have children. At the same time, homeowners can also obtain more income through the sale of real estate or mortgage loans, which further improves their ability to raise children, thereby increasing their willingness to bear children. To sum up, due to the different responses of households with different incomes to house prices, house prices have risen, and the utility of homeless families and families with loan repayments has declined, which has a negative substitution effect on fertility. At the same time, families with higher incomes have greater wealth effects on real estate, Has a positive substitution effect and income effect on the reproductive behavior of high-income families with houses and no loans.

\section{CONCLUSIONS AND RECOMMENDATIONS}

Based on data and theoretical analysis, this paper studies the impact of rising house prices on fertility behavior in recent years, and draws the following conclusions: socioeconomic factors have a cumulative effect on family fertility behavior; house prices have a positive spatial auto-correlation on both fertility and fertility behavior ; Rising house prices have changed the structure of family budgets, which should change the shadow price of births, leading to a decline in the fertility rate and changes in the expected demographic structure. Based on the above research conclusions, high house prices have become a "contraceptive" that delays family births. Therefore, on the basis of active population policies, it is necessary to control house prices in a targeted manner, reduce the pressure on house consumption of young families, and budget space for young families to have a children. This article proposes the following suggestions for reversing the decline in fertility:

1. Increase the area of affordable house, vigorously develop public rental house and low-rent house construction, and reduce the pressure on low-income families, especially newlyweds, to buy houses.

2. Increasing the supply of small and medium-sized house can effectively increase the house demand of low-income people and newly married couples, thereby reducing the inhibitory effect of house prices on reproductive behavior. 
3. Strictly control speculative demand. Abnormal demand such as real estate speculation in some of our country's real estate market is too prosperous, leading to rising house prices. There are obvious differences between the eastern and western regions. To control the unreasonable rise in house prices, these non-rigid demand needs must be controlled, so as to ensure that families with rigid needs and house People have their own homes. At the same time, encourage the supply of multisubject house, increase affordable house, and provide more financial tools for low-income earners.

4. Reduce the cost of family childbirth. For example, in the reform of personal tax in China last year, a certain tax reduction or exemption is given based on whether the family has children and parental support, taking into account the family's living conditions. The current policy mentions childbirth allowances. If a certain level of two-child or three-child conditions is met, the government can provide certain incentives for childbirth, which can effectively reduce the cost of childbirth for newly-married couples and encourage a moderate increase in childbirth.

5. Increase government spending on education and reduce the burden on family education. Not only should the expenditure of compulsory education be increased, but also certain policy support should be given to related education enterprises and training institutions, such as policy subsidies or tax reductions, etc., to reduce the cost of children's education. Promoting educational equity and ensure that the provision of educational public goods and services has a positive impact on family fertility decision-making.

\section{REFERENCES}

[1] Lutz, Wolfgang, William P. Butz, and Samir KC (Eds). 2014. World Population and Human Capital in the Twenty-First Century. Oxford: Oxford University Press.

[2] Makthus T. An Essay on the Principle of Population, as It Affect the Future Improvements of Society, with Remarks on the Speculations of Mr. Godwin, M. Condorcet, and other Writes[D]. London; J. Johnson, 1798

[3] Butz, W., and M. Ward, "The Emergence of Count Ercyclical U.S. Fertility", American Economic Review, 1979, 69(3), 318-328.

[4] Easterlin, R., "The Conflict between Aspirations and Resources", Population and Development Review, 1976, 2(4), 417-425

[5] Gronau, R. "The Effect of Children on the House wives Value of Time", Journal of Political Economy, 1973, 81(2), 168-199 
[6] Willis, R.,"A New Approach to the Economic Theory of Fertility Behaviour", Journal of Political Economy, 1973, 81(2), 14-64.

[7] Becker, G., and K. Murphy, Social Economics: Market Behaviour in a Social Environment. Cambridge, Mass: Harvard University Press, 2003

[8] Sprague, A., "Post-war Fertility and Female Labor Force Participation Rates", Economic Journal, 1988, 98(2), 682-700

[9] Willis, R., "A New Approach to the Economic Theory of Fertility Behavior", Journal of Political Economy, 1973, 81(2), 14-64.

[10] Yakita A. Uncertain lifetime, fertility and social security[J]. Journal of Population Economics,2001,14(4):635-640

[11] Yi J J, Zhang J S. The effect of house price on fertility: Evidence from Hong Kong[J]. Economic Inquiry,2010,48(3):635-650.

[12] Laeven L, Popov A. Waking Up from the American Dream: On the Experience of Young Americans during the House Boom of the 2000s[J]. Journal of Money, Credit and Banking, 2017,49(5):861-895

[13] Chen W Y. Does house cost affect birth rates in Taiwan? The ADL test for threshold cointegration[J]. Journal for Economic Forecasting,2013,16 (3) : 90-103.

[14] Hui ECM, Zheng X, Hu J. House price, elderly dependency and fertility behaviour [J]. Habitat International,2011,36 (2):304-311.

[15] Simon J C, Tamura R.Do higher rents discourage fertility? Evidence from U.S. cities:19402000[J]. Regional Science and Urban Economics,2009,39 (1) :33-42.

[16] Song Deyong, Liu Zhangsheng, Gong Yuanyuan. The impact of rising house prices on the willingness of urban residents to give birth to the second child[J]. Urban Issues, 2017, (3): 67-72.

[17] Zhang Xinjie. Income gap, children's needs and differences in reproductive behavior[D]. Shandong University, 2017

[18] Xu Dianqing, "House Prices and Bubble Economy". Beijing: Mechanical Industry Press, 2006.

[19] Yi Junjian, Yi Xingjian. Rising house prices and long-term decline in fertility: An empirical study based on Hong Kong[J] Economics (Quarterly), 2008, (4): 962-982. 


\section{International Journal of Education and Social Science Research}

Vol. 4, Issue.6, Nov-Dec 2021, p no. 385-397

\section{Editor Information}

Dr. Liu Yue is working at Wenzhou Polytechnic, China, teaching for Real Estate Operation and Management, was graduated in Jose Rizal University, Philippines, has a more than ten years of corporate management at Shandong Weizhilai Group and Shanghai Xunyu Industrial. Have more than five years of asset management experience.

Mr. Wang Zhiwen is a senior college student in Wenzhou Polytechnic, Head of the Learning Department of the Student Union and the class learning committee. Participated in the activities organized by the school for many times, have certain experience and practical ability in organization and planning.

Miss. Lin Sisi is a senior college student in Wenzhou Polytechnic, Head of the Service Department of the Student Union. Good organizational communication skills, proficient in Office software, PS. Optimistic and cheerful, always ready to help others. 